\title{
An audit of knowledge, attitude and sexual practise of HIV positive patients in Beaumont Hospital.
}

\author{
David McMahon ${ }^{1 *}$, Samuel McConkey ${ }^{1,2}$ \\ From 4th International Conference for Healthcare and Medical Students (ICHAMS) 2014 \\ Dublin, Ireland. 24-25 October 2014
}

\section{Background}

This study explores the effectiveness of information provision in the HIV clinic in Beaumont Hospital, determining whether the patients understand the information provided and change their beliefs and practices as a result.

\section{Methods}

Patients were asked a series of questions in a structured interview. The information was then analysed on a population basis by ethnicity and viral load.

\section{Results}

684 questions were asked to ascertain the patient's knowledge of HIV transmission with an $82 \%(\mathrm{n}=559)$ rate of correct answers. $72 \%(n=37)$ of those who had sex in the past year in this study stated that they had not had sex without a condom in that period.

\section{Conclusions}

There is room for improvement in knowledge of transmission in the clinic. An 8\% gap existed between Irish patients (89\%) and all other patients (81\%) in the area of HIV transmission. The understanding that antiretroviral drugs can aid in preventing HIV transmission is lacking in many patients. Many patients have changed their sexual practices while attending the clinic to protect both themselves and their partners.

\section{Authors' details}

'Royal College of Surgeons in Ireland, Dublin 2, Ireland. 'Beaumont Hospital, Dublin 9, Ireland.

Published: 27 October 2015

${ }^{1}$ Royal College of Surgeons in Ireland, Dublin 2, Ireland

Full list of author information is available at the end of the article
doi:10.1186/1753-6561-9-S7-A8

Cite this article as: McMahon and McConkey: An audit of knowledge, attitude and sexual practise of HIV positive patients in Beaumont Hospital.. BMC Proceedings 2015 9(Suppl 7):A8.
Submit your next manuscript to BioMed Central and take full advantage of:

- Convenient online submission

- Thorough peer review

- No space constraints or color figure charges

- Immediate publication on acceptance

- Inclusion in PubMed, CAS, Scopus and Google Scholar

- Research which is freely available for redistribution

Submit your manuscript at www.biomedcentral.com/submit
() Biomed Central 